Review article

\title{
Low-Carbon Tourism Approach as an Alternative Form for Tourism Development: A Review for Model Development
}

\author{
Fauziah Che Leh ${ }^{1 *}$, Nor Kalsum Mohd Isa ${ }^{1}$, Mohd Hairy Ibrahim ${ }^{1}$, Mansor \\ Ibrahim $^{2}$, Mohd Yazid Mohd Yunos ${ }^{3}$ and Johan Afendi Ibrahim ${ }^{4}$ \\ ${ }^{1}$ Department of Geography and Environment, Faculty of Human Sciences, Universiti Pendidikan Sultan Idris, \\ 35900 Tanjong Malim, Perak, Malaysia \\ ${ }^{2}$ Department of Urban and Regional Planning, Kulliyyah of Architecture and Environmental Design, Universiti \\ Islam Antarabangsa Malaysia, 53100 Gombak, Selangor, Malaysia \\ ${ }^{3}$ Department of Landscape Architecture, Faculty of Design and Architecture, Universiti Putra Malaysia, 43400 \\ Serdang, Selangor, Malaysia \\ ${ }^{4}$ School of Tourism, Hospitality and Event Management, College of Law, Government \& International Studies, \\ Universiti Utara Malaysia, 06010 Sintok, Kedah, Malaysia
}

\begin{abstract}
The tourism industry is a major contributor to the gross domestic product of several countries, including Malaysia. However, recent tourism growth has led to increase the industry's carbon dioxide $\left(\mathrm{CO}_{2}\right)$. Low-carbon tourism, therefore, needs to be introduced to the sector to help curb global climate change. A comprehensive understanding of lowcarbon tourism needs to be developed to achieve this goal. This article looks at the relevant studies in the literature using content analysis. By adopting a qualitative methodology, the article collected and assessed measurements of tourism's carbon emissions and examined the effects of implementing a low-carbon tourism programme. Some of the low-carbon strategies were listed by going through

ARTICLE INFO

Article history:

Received: 10 July 2021

Accepted: 11 September 2021

Published: 08 December 2021

DOI: https://doi.org/10.47836/pjssh.29.4.19

E-mail addresses:

fauziah@fsk.upsi.edu.my (Fauziah Che Leh)

norkalsum@fsk.upsi.edu.my (Nor Kalsum Mohd Isa)

hairy@fsk.upsi.edu.my (Mohd Hairy Ibrahim)

profmansor@iium.edu.my (Mansor Ibrahim)

mohdyazid@upm.edu.my (Mohd Yazid Mohd Yunos)

afendi@uum.edu.my (Johan Afendi Ibrahim)

* Corresponding author

the entire implementation process of lowcarbon tourism as an alternative form of tourism development. The discussion also focuses on how Covid-19 can influence lowcarbon tourism development. A blueprint for a low-carbon recovery proposed by the Organisation for Economic Co-operation and Development (OECD) is also presented at the end of the paper. The results of this study can be used as a basis for policy
\end{abstract}


development and further research on lowcarbon tourism in industry sub-sectors worldwide.

Keywords: Blueprint, carbon dioxide, climate change, Covid-19, emissions, low-carbon tourism

\section{INTRODUCTION}

The Organisation for Economic Cooperation and Development (OECD, 2010) has highlighted several challenges for the tourism industry by considering the factors that will affect its long-term development. These include globalisation and market change, the impact of tourism across the economy, climate change and sustainability, the knowledge economy, human resources and productivity, and competitiveness. According to Tang et al. (2018), the rapid growth in the tourism industry may increase the carbon dioxide $\left(\mathrm{CO}_{2}\right)$ emissions that cause climate change. Greenhouse gas (GHG) emissions from various tourism activities have already harmed the natural environment. GHG is a major cause of global warming; it originates in the large amounts of energy consumed in urban areas that carry out various intensive economic activities (Ministry of Land, Infrastructure, Transport and Tourism Japan [MLITTJ], 2011). One of the major contributors of GHG emissions is $\mathrm{CO}_{2}$, which is produced when fossil fuels such as coal, oil, and natural gas are burned and when there is a change in land use, such as deforestation (Sunlu, 2003). Therefore, the increasing use of electricity and transportation in tourism contributes to the uncontrolled release of $\mathrm{CO}_{2}$, which leads to climate change.
Chiesa and Gautam (2009) set out five clusters in the travel and tourism sector that contribute to carbon emissions: land transport, air transport, water transport, accommodation, and tourism activities. Each cluster contributes directly and indirectly to GHG emissions. According to Tang et al. (2018), transport accounts for $75 \%$ of $\mathrm{CO}_{2}$ emissions in the sector, followed by accommodation and catering (21\%) and tourism activity (4\%). Similarly, the OECD (2010) estimated that the tourism industry contributes up to $5.3 \%$ of global GHG emissions, with transport accounting for $75 \%$. Direct carbon emissions are from sources such as transportation, which uses fuel and energy, the restaurant and accommodation sectors, which use electricity and gas, and other tourism activities (Fang, 2011). Indirect carbon emissions occur from manufacturing processes, infrastructure development, airline offices, and travel agents indirectly involved in tourism. Therefore, indirect carbon emissions need to be considered and addressed when calculating tourism industry's carbon footprint, as their effects can also lead to global warming.

As Sunlu (2003) explained, the relationship between tourism and the environment is complex because many tourism activities have a detrimental effect on nature, even potentially destroying it. The construction of infrastructures, such as roads and airports, and tourism facilities, including resorts, hotels, restaurants, shops, golf courses, and marinas, is how tourism can negatively impact the environment. The 
recent increase in tourism may lead to the depletion of natural resources. However, tourism has also the potential to impact the environment by introducing protection and conservation measures positively. The tourism industry must work with governments and local communities to create sustainable activities. A thriving, sustainable tourism industry can contribute to socio-economic development, which will benefit communities. Both the environment and manufactured infrastructures need to be preserved to benefit the sector and healthy living. Therefore, efforts to promote lowcarbon alternatives worldwide are necessary to maintain tourism as a key industry in the long term.

\section{LITERATURE REVIEW}

\section{Low-Carbon Tourism}

Currently, low-carbon lifestyles are spreading in many countries worldwide. The tourism sector is part of this trend by making the low-carbon approach one of its goals. Although low-carbon tourism (LCT) is still being explored, many stakeholders, including governments and businesses, are working together to make LCT a success. According to Yang (2015), LCT requires joint efforts from governments, industry, and universities to grow efficiently and environmentally friendly. Moreover, LCT can support the development of a low-carbon economy. Proposed by the British government in 2003, the low-carbon economy aims to improve living standards by increasing the use of natural resources that have less impact on the environment and increase economic production in the long run (Huang \& Deng, 2011). Shi and Peng (2011) explained that a green economy could be achieved with low-carbon energy consumption, low-pollution production, and low-carbon emissions. In the era of globalisation, increased tourism activities, human behaviour, and culture are the greatest contributors to carbon emissions (Bhaktikul et al., 2020). Therefore, the implementation of LCT needs to be intensified to succeed in achieving a low-carbon economy. Most of the sector's energy consumption comes from transportation and infrastructure operation and development. Formally, the concept of LCT was proposed in May 2009 at the World Economic Forum in a report on low-carbon travel and the tourism industry (Huang \& Deng, 2011). LCT practices can protect the environment and culture and positively contribute to the lives of local people.

Scholars describe LCT in different ways. Wang et al. (2019) argue that LCT is a way of achieving maximum tourism experience with new forms of travel planning and a way for the industry to provide higher social, economic, and environmental benefits to the community. Similarly, Thongdejsri et al. (2016) believe that LCT is an effort to reduce carbon emissions to a minimum when conducting tourism activities. They add that the low-carbon technology introduced thanks to LCT is a useful undertaking that provides greater benefits to the economy, society, and the environment. According to Yang (2015), LCT is part of developing a low-carbon economy supported by clean technology. LCT can 
help reduce carbon emissions and energy consumption while aiming for sustainable economic and environmental development. LCT can also provide a high-quality tourism experience by reducing entertainment, shopping, sightseeing, transportation, and accommodation pollution. Xiong (2017) maintains that LCT is a form of environmentally friendly tourism with high efficiency and sustainable production methods; thus, LCT offers economic, social, and environmental benefits.

According to Shi and Peng (2011), there are two types of low-carbon tourist attractions: absolute and relative. An absolute tourist attraction provides comprehensive low-carbon services of the highest possible standard. A relative tourist attraction offers limited travel services with energy-efficient residential facilities and eco-friendly travel equipment. Thongdejsri et al. (2016) argue that national and local government agencies need to cooperate and adopt low-carbon management technologies to implement the LCT concept at the policy level, thus contributing to a clean environment. The support of tourists is also needed to strengthen low-carbon practices in the sector. Essentially, every stakeholder - the government, the private sector, businesses, and tourists - should all play their role in promoting LCT.

Tourism components such as hotels, airports, roads, trains, heating and cooling equipment, and various leisure activities contribute to global warming. One of the main culprits in this sense is the method of travel. We suggest several activities that promote LCT, such as walking and cycling. Trains are another means of transport that can be highlighted for ecotourism because they have a low impact on the environment. At present, the popularity of railway lines has never been greater because of the increase in road traffic. The use of public bicycles in urban areas worldwide is also a very popular trend currently and is recognised as a low-carbon travel method. Longer walking and cycling trips play an important role in the sustainability of tourism, both economically and environmentally. Over the past hundred years, itineraries in popular tourist destinations that possess deep historical traditions have developed into trendy long-distance walking routes. For example, Penang Heritage Trail and Melaka City offer a self-guided walking tour with a map to discover the history of a UNESCO World Heritage Site that is being carefully restored, maintained, and improved.

Cycling is an improvised version of LCT that has become more popular over the past 40 years. Although cycling is often in line with regional and national policies for sustainable tourism, this alternative has several barriers. For example, poor integration with public transport and a lack of reliable infrastructure hinder market development. Therefore, the parties involved need to provide traffic-free routes through urban and rural areas with gentle gradients to encourage people to use bicycles for recreational purposes. Several sites have introduced LCT practices by promoting rickshaws, bicycles, and rental scooters. Rickshaws are the most common means 
of transport found in Kota Bharu, Malacca City, and Komtar. Furthermore, Kuala Lumpur, Putrajaya, and Cyberjaya have promoted numerous bicycle and scooter rental services. Beam and Neuron are among the companies that provide rental services in Malaysia. In short, by adopting LCT, we can reduce our carbon footprint to sustain nature for future generations.

\section{Carbon Footprint}

A carbon footprint (previously known as an ecological footprint) shows the potential for global warming. A carbon footprint is the quantity of $\mathrm{CO}_{2}$ emissions from certain activities. By calculating the carbon footprint of activity, we can manage and mitigate emissions. Significant sources of emissions can thus be identified and reduction and efficiency prioritised for the benefit of the environment (Pandey et al., 2010). It highlights the importance of carbon footprint calculation to solve the pollution problem. The notion of an ecological footprint refers to the biologically productive land and sea areas needed to sustain a particular human population. From this perspective, a carbon footprint refers to the soil needed to absorb all the $\mathrm{CO}_{2}$ produced by a person in their lifetime. The idea of a carbon footprint is now quite familiar among the public and a major concern for the world's environmental agenda. A carbon footprint can be changed by shifting to more sustainable practices.

A carbon footprint measures the $\mathrm{CO}_{2}$ emissions produced directly or indirectly by activity or throughout the life cycle of a product (Durojaye et al., 2020; Fang, 2011). From 1850 to 2015, the average surface air temperature has increased by $1.53^{\circ} \mathrm{C}$ (probability range from $1.38^{\circ} \mathrm{C}$ to $1.68^{\circ} \mathrm{C}$ ), while the global mean surface temperature has risen by $0.87^{\circ} \mathrm{C}$ (probability range from $0.75^{\circ} \mathrm{C}$ to $0.99^{\circ} \mathrm{C}$; Intergovernmental Panel on Climate Change [IPCC], 2019). A record rise in temperature of $0.87^{\circ} \mathrm{C}$ has urged climate scientists to focus on immediate actions to curb global warming. Tourism has one of the largest carbon footprints in the economy. Tourist activities involve the movement of humans, which accounts for about $50 \%$ of global traffic, including air traffic, which contributes around $2.5 \%$ of global $\mathrm{CO}_{2}$ emissions. As these figures show, tourism is a significant contributor to GHG emissions. For example, air travel is one of the fastest-growing sources of GHG emissions. Sunlu (2003) predicted an increase in international tourists from 594 million in 1996 to 1.6 billion in 2020, but it is not achieved due to the Covid-19 pandemic. Becken (2009) emphasised the importance of distinguishing the global carbon footprint of tourism from the footprints of specific destinations. The global footprint includes all tourism activities ranging from international air travel to transportation, types of residence, and visits to places of interest. In contrast, national footprints focus on emissions that occur within domestic borders. However, national carbon footprint analysis rarely includes the climate-related effects of international air travel, which is the largest contributor of $\mathrm{CO}_{2}$ emissions compared 
to all other sources of emissions in the economy. A comprehensive measure is therefore needed to the worst impacts of excessive $\mathrm{CO}_{2}$ emissions.

Apart from transportation, resort development is also a major contributor to carbon emissions. Bohdanowicz et al. (2001) estimate that a typical hotel devotes $50 \%$ of its energy consumption to heating and air-conditioning, $25 \%$ to catering, $15 \%$ to hot water, and 5\% each to lighting, and other activities. Salehudin et al. (2015) have suggested renewable energy as an alternative energy source to support the tourism industry in Malaysia, especially in resorts located on islands, where there are many sources of renewable energy. Renewable energy can improve economic competitiveness and raise the profile of LCT in Malaysia, thus ensuring its future prosperity. The Malaysian government supports this effort by promoting the use of natural energy sources.

Other human activities that have significant carbon footprints include the use of vehicles and heavy machinery, electrical equipment for daily chores (e.g., washing machines) and other items that use electricity and fuel to function (Durojaye et al., 2020). Increased carbon footprints raise the concentration of GHGs, which leads to severe global warming. As the understanding of this phenomenon has improved, concerns about preventing it have become more pressing. In 1997, the Kyoto protocol established that developed economies and several developing economies should reduce their emissions from five types of GHGs $\left(\mathrm{CO}_{2}\right.$, methane, nitric oxide, perfluorocarbons, and hydrofluorocarbons) by at least $5.2 \%$ compared to 1990 levels in 2008-2012 (United Nations [UN], 1998, as cited by Durojaye et al., 2020). Thus, low-carbon products and the adoption of low-carbon practices can solve the global warming problem. Malaysia is no exception when it comes to the increase of GHG emissions globally. As Figure 1 shows, in 2019, Malaysia produced 250 million tons of $\mathrm{CO}_{2}$ from burning fossil fuels for energy and cement production. The nation's emissions started increasing drastically in 1950 as part of the age of development.

Green transportation can solve the biggest problem in terms of $\mathrm{CO}_{2}$ emissions in the tourism sector globally. Fang (2011) explains that green transportation aims to encourage people to use the public transport offered by city governments. For example, Taipei City provides various cloud-based transportation services, including electric golf carts, to facilitate travel from one village to another. These initiatives can reduce the use of private vehicles, thus diminishing carbon emissions. Low-carbon practices can also lessen traffic congestion. Salehudin et al. (2015) recommended that tourism facilities replace fossil fuels and other nonrenewable energy sources with renewable energy to reduce $\mathrm{CO}_{2}$ emissions. Mohamad and Jaafar (2012) found four energy sources with a high potential to be developed in Malaysia: solar, wind, hydro, and nuclear. However, the environment should be continuously monitored to ensure a balanced approach so that these developments do 


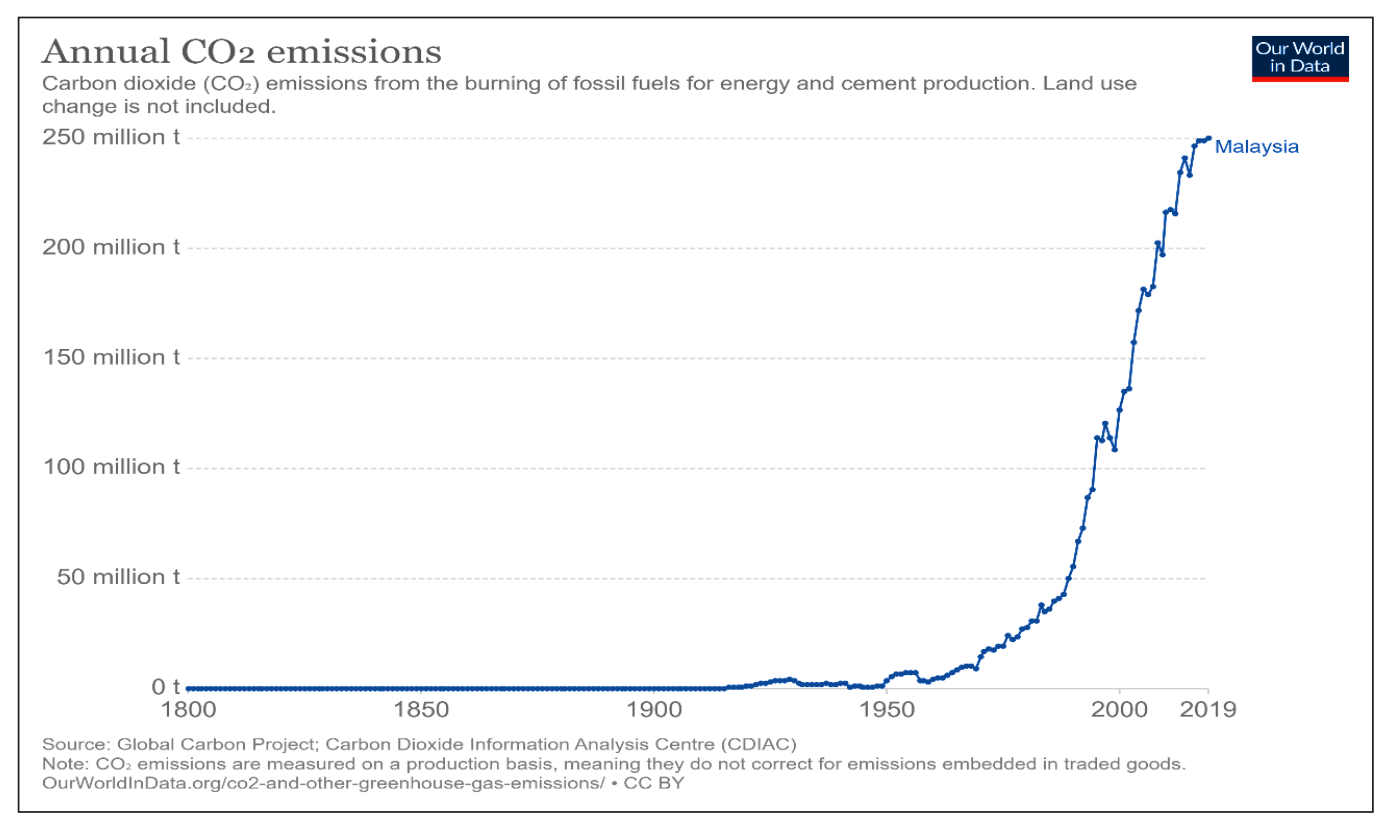

Figure 1. $\mathrm{CO}_{2}$ emissions in Malaysia based on Our World in Data

Source: https://ourworldindata.org/co2-emissions

not pose a risk to life. Furthermore, the global carbon emissions of tourism are not measured satisfactorily. Therefore, the environmental problems caused by tourism activities' carbon footprint still need to be resolved.

\section{METHODS}

This research promotes LCT as an alternative form of tourism development in various industry sub-sectors. A comprehensive understanding of LCT needs to be achieved. A literature search was conducted in leading electronic journal databases (Science Direct and Scopus) with "low-carbon tourism" keywords.

This research used content analysis to examine the relevant literature. The aim was to identify measurements of tourism's carbon emissions, explain the low-carbon strategy, and assess the effects of implementing an LCT programme. The study also discusses how Covid-19 can influence LCT. Finally, it looks at the blueprint for a low-carbon recovery proposed by the OECD. The study's findings are useful as a starting point for future study, especially when formulating a guide for LCT development best practices. Moreover, regarding the Malaysian context, the study offers insights into the sustainability principles required for the future development of tourism to stakeholders such as the Ministry of Tourism, the Town and Country Planning Department, and university researchers.

\section{RESULTS}

\section{Tourism's Carbon Emissions}

In its effort to seek economic gain, the tourism industry ignores the damage done 
to the environment. Xiong (2017) showed how the impact of tourism on rural areas had destroyed the cultural and natural landscape in Jiangxi, China. Without proper knowledge of the environment and the LCT approach, the tourism industry can cause large negative impacts in the areas where it operates. According to Sunlu (2003), the negative effects of tourism occur when the number of visitors exceeds the reception capacity of the environment and the available tourist facilities in a location. This situation affects natural areas worldwide. Popular destinations have been closed because of excessive visits that cause damage to the environment, including Mount Everest, Boracay Island, and Maya Bay ("5 destinasi popular ini ditutup", 2019). The impact of improperly planned tourism can also lead to soil erosion, increased pollution, dumping of waste into the sea, loss of natural habitats, increased stress on endangered species, and high susceptibility to forest fires (Sunlu, 2003). As a result, local communities have to compete to access increasingly scarce resources. Lee (2011) argued that because the tourism industry affects climate change, a direct change is required in tourism's resources and socioeconomic policy. Therefore, there is an urgent need for a new low-carbon policy to take recovery measures before the situation becomes too critical.

Tourism development is contributing to the depletion of natural resources, including water and land. Water resources are essential to all tourism activities, including hospitality, landscaping, and personal use. Careful use of water should thus be implemented to ensure an adequate supply for residents and future tourists. Tourism development can also affect forest ecology. Without careful planning, widespread deforestation for firewood and land clearing for development destroy natural areas important for stabilising ecosystems (Sunlu, 2003). In addition to recreational purposes, biodiversity is important for supplying food, medicinal and industrial products, and for expanding humans' knowledge of the richness of life (Zakaria \& Hasbullah, 2009). Excessive tourism activities degrade our biological diversity, which may lead to natural disasters such as floods and droughts, while human-induced ecosystem stress causes pollution and climate change (Sunlu, 2003). As one of the thriving industries in the world economy, tourism should sustain both flora and fauna and protect the mountain, marine, and coastal ecosystems. After all, the loss of biodiversity will lead to the loss of tourism potential.

Several studies have proven that increases in tourism and travel contribute to the worsening of global climate change (Bhaktikul et al., 2020). Therefore, scholars have started promoting LCT implementation in strategies, practices, organisations, governments, and operators (Bhaktikul et al., 2020; Lee, 2011; MLITTJ, 2011; Yang, 2015). As a result, more LCT initiatives are being undertaken worldwide, such as building low-carbon cities, low-carbon hotels, and scientific museums based on low-carbon themes (Huang \& Deng, 2011). Therefore, behavioural changes 
are necessary to diminish the impact of tourism on the environment by promoting an approach with fewer carbon emissions.

We need to introduce a new and more efficient approach to maintaining biodiversity and the natural environment for the enjoyment and benefit of all living things. Among the proposed measures to develop LCT are those to create low-carbon tourist destinations and provide low-carbon facilities, thus preserving tourism while absorbing carbon from the atmosphere (Huang \& Deng, 2011). Table 1 shows the strategies put forward by various researchers to reduce GHG emissions in the tourism industry.

Table 1

Low-carbon tourism strategies

\begin{tabular}{|c|c|c|}
\hline No. & Strategies & Description \\
\hline 1 & $\begin{array}{l}\text { Reduce energy } \\
\text { consumption } \\
\text { through LCT } \\
\text { development }\end{array}$ & $\begin{array}{l}\text { i. Monitor total energy consumption and carbon emissions in the tourism } \\
\text { industry. } \\
\text { ii. Provide many green areas to reduce heat islands and increase insulating } \\
\text { effects. } \\
\text { iii. Increase the implementation of energy-saving measures and raise awareness } \\
\text { of the importance of environmental care for all the groups involved. } \\
\text { iv. Choose local products offered in the tourist area. } \\
\text { v. Provide adequate parking spaces and racks to encourage the use of bicycles } \\
\text { in tourist areas. }\end{array}$ \\
\hline 2 & $\begin{array}{l}\text { Adopt } \\
\text { energy-saving } \\
\text { technologies } \\
\text { and implement } \\
\text { emissions } \\
\text { reductions } \\
\text { through LCT } \\
\text { development }\end{array}$ & $\begin{aligned} & \text { i. } \text { Replace diesel boilers with gas boilers. } \\
& \text { ii. Introduce a system of waste-heat collection. } \\
& \text { iii. Replace fluorescent lightbulbs with low-consumption LEDs. } \\
& \text { iv. } \\
& \text { v. Install water-saving and rainwater collection equipment. } \\
& \text { vi. Introduce environmental management and operation systems. } \\
& \text { vii. Promote energy-saving technologies and emissions reductions in low- } \\
& \text { carbon tourist attractions. }\end{aligned}$ \\
\hline 3 & $\begin{array}{l}\text { Increase the use } \\
\text { of renewable } \\
\text { energy in LCT } \\
\text { development }\end{array}$ & $\begin{array}{l}\text { i. Install solar panels and hydrogen fuel cells to supply hot water. } \\
\text { ii. Introduce water and wind power generation. } \\
\text { iii. Introduce hydrogen cell vehicles and electric cars. } \\
\text { iv. Switch to biodiesel fuel. }\end{array}$ \\
\hline 4 & $\begin{array}{l}\text { Balance and } \\
\text { reduce GHGs } \\
\text { through the } \\
\text { Carbon Offset } \\
\text { Programme }\end{array}$ & $\begin{array}{l}\text { i. Allocate enough funds to environmental groups to balance carbon emissions. } \\
\text { ii. Increase the area of the green belt. } \\
\text { iii. Take part in area conservation programmes or environmentally friendly } \\
\text { species conservation. } \\
\text { iv. Conduct tree-planting campaigns with staff, tourists, and the public. } \\
\text { v. Create air ducts in aircraft to reduce fuel consumption and make aircrafts } \\
\text { lighter. } \\
\text { vi. Use alternative fuels such as biofuels to save energy and reduce emissions. } \\
\text { vii. Choose electric, non-motorised, or carbon-free transportation. } \\
\text { viii. Encourage the construction of garden houses in tourist areas. }\end{array}$ \\
\hline 5. & $\begin{array}{l}\text { Raise awareness } \\
\text { of LCT in } \\
\text { the media } \\
\text { and through } \\
\text { education }\end{array}$ & $\begin{array}{l}\text { i. } \\
\text { ii. } \\
\text { iii. } \\
\text { iveplace the use of paper with an e-ticketing system. } \\
\text { v. } \\
\text { vi. Encourage the use of own bags for shopping. } \\
\text { vi. } \\
\text { Use the media to promote and explain LCT. }\end{array}$ \\
\hline
\end{tabular}


Table 1 (continue)

\begin{tabular}{|c|c|c|}
\hline No. & Strategies & Description \\
\hline 6. & $\begin{array}{l}\text { Create low- } \\
\text { carbon tourist } \\
\text { attractions }\end{array}$ & $\begin{array}{l}\text { i. Plan systematically to create beautiful tourist destinations as part of a } \\
\text { model of the circular economy. } \\
\text { ii. Promote eco-labels to protect the natural landscape and maintain its } \\
\text { original condition. } \\
\text { iii. Provide energy-efficient tourism products and attractions, optimal } \\
\text { structures, and demand and supply of clean energy; actively explore new } \\
\text { clean energy applications. } \\
\text { iv. Introduce business models and management of low-carbon tourist } \\
\text { attractions. } \\
\text { v. Encourage the use of less-polluting vehicles, such as electric scooters. }\end{array}$ \\
\hline 7. & $\begin{array}{l}\text { The role } \\
\text { of tourist } \\
\text { administrative } \\
\text { departments } \\
\text { in LCT } \\
\text { development }\end{array}$ & $\begin{array}{l}\text { i. Implement laws and regulations to standardise and institutionalise LCT. } \\
\text { ii. Introduce policies that drive the construction of low-carbon tourism } \\
\text { attractions. } \\
\text { iii. Set LCT standards and action plans. } \\
\text { iv. Follow the standard of low-carbon business implementation systems in } \\
\text { tourist areas. } \\
\text { v. Create a low-carbon system for area attractions, transportation, and tourist } \\
\text { hotels. } \\
\text { vi. Help tourism enterprises step up energy-saving efforts, reduce CO2 } \\
\text { emissions, and use renewable energy. } \\
\text { vii. Support LCT enterprises with tax cuts, subsidies, government } \\
\text { procurement, and green credit. } \\
\text { viii. Provide special funds to encourage the development of low-carbon } \\
\text { projects and technologies for the tourism sector. } \\
\text { ix. Strengthen the marketing of LCT to increase its public awareness. } \\
\text { x. Establish collaborations between tourism administrators and the media to } \\
\text { enhance tourist awareness of LCT. } \\
\text { xi. Expand international exchanges and cooperation; introduce international } \\
\text { carbon modelling for tourism management. }\end{array}$ \\
\hline
\end{tabular}

8. The role of travel i. Support efforts to promote LCT, develop products, and use LCT routes to agencies in LCT development meet the needs of tourists.

ii. Design detailed plans for hiking and cycling routes to guide tourists back to nature, protect the environment, reduce carbon emissions, and ensure the continued development of tourism.

iii. Adopt low-carbon activities in every domain, including reducing paper consumption, managing waste disposal, avoiding disposable cutlery, controlling the number of visitors, protecting forest and green areas, providing ecological parking, encouraging the use of low-carbon vehicles and renewable energy sources, namely hydro, wind, and solar.

\begin{tabular}{lll}
\hline 9. $\begin{array}{l}\text { The role of } \\
\text { hotels in LCT } \\
\text { development }\end{array}$ & i. & $\begin{array}{l}\text { Enhance low-carbon management efforts through the setting and } \\
\text { popularisation of green standards. }\end{array}$ \\
$\begin{array}{lll}\text { Promote low-carbon technology, renewable energy sources, new materials, } \\
\text { and intelligent control systems in the manufacturing and using electrical } \\
\text { goods. }\end{array}$ \\
\hline $\begin{array}{l}\text { The role of } \\
\text { tourists }\end{array}$ & i. & $\begin{array}{l}\text { Disseminate the benefits of LCT-related activities through various } \\
\text { advertising methods. } \\
\text { Support and choose the LCT industry to increase the demand and supply } \\
\text { of LCT activities. }\end{array}$ \\
\hline
\end{tabular}

Source: Bhaktikul et al. (2020), Huang \& Deng (2011), Lee (2011), Shi \& Peng (2011), Tang et al. (2018) 
LCT principles must be applied to the entire tourism process, including catering, accommodation, sightseeing, shopping, and entertainment, to overcome the long-term negative effects of the industry. In addition to contributing to a cleaner environment, LCT can generate new employment and income.

\section{An LCT Model}

The concept of LCT has been developed about ecotourism and sustainable tourism. However, there are differences between these concepts regarding connotation, scope, and how to realise them. Ecotourism focuses on saving limited resources and vulnerable environments, thus emphasising natural travel, less exploitation, and human intervention. LCT is an effort to minimise the impact of conventional tourism by adopting low-carbon technologies, creating low-carbon environments, and adopting low-carbon lifestyles. Figure 2 explains the relationship between LCT, ecotourism, and sustainable tourism. LCT acts as a basic platform for ecotourism and becomes a path to achieve sustainable tourism.

Yang (2015) believes that LCT is essentially an expansion of ecotourism. LCT promotes low-carbon production and operation in each itinerary. For example, it uses new technologies and energy sources to reduce energy consumption and waste in all accommodations. It can thus reduce GHG emissions while still expanding the tourism economy. Lee (2011) argues that current green tourism stems from an older idea of eco-friendly development (Figure 3).

Huang and Deng (2011) produced a model of LCT development in the context of the leisure economy. This model was designed to reduce tourists' carbon footprint by creating low-carbon attractions and facilities. Figure 4 shows the flows through which LCT is achieved in the leisure economy.

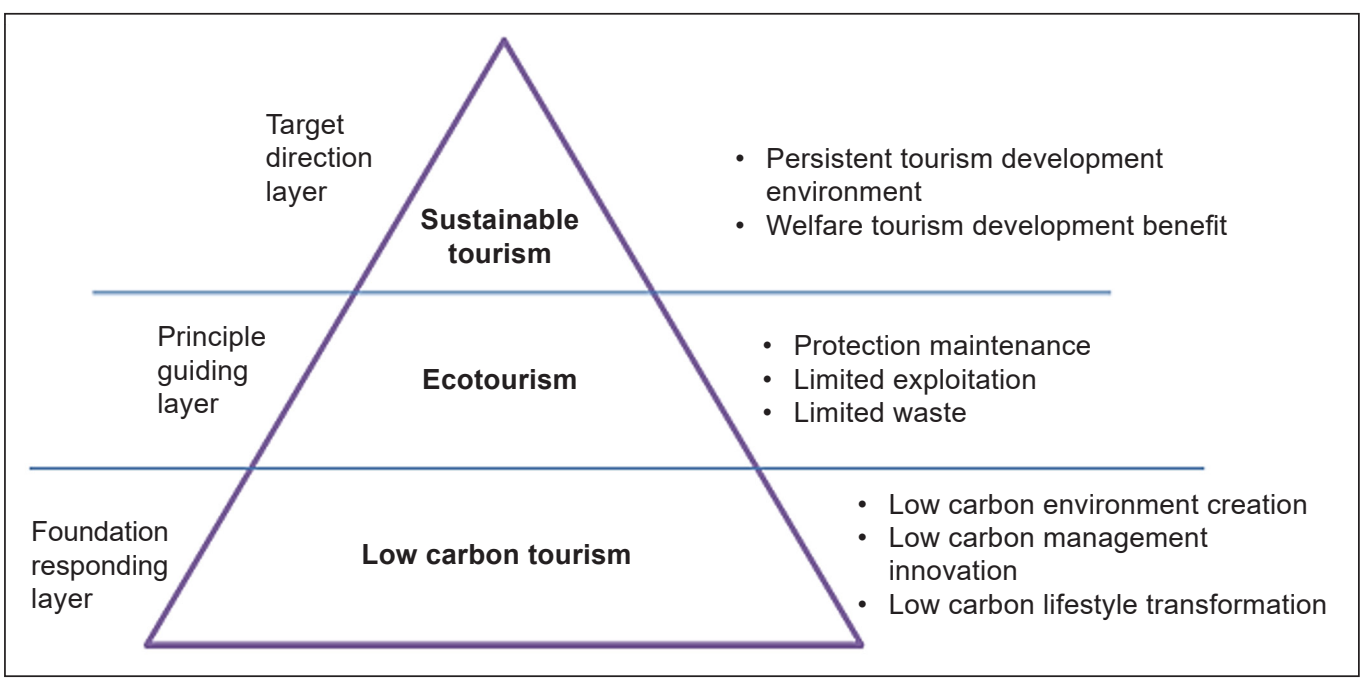

Figure 2. Modern tourism development modes pyramid

Source: Yuan (2012) as cited in Thongdejsri et al. (2016) 


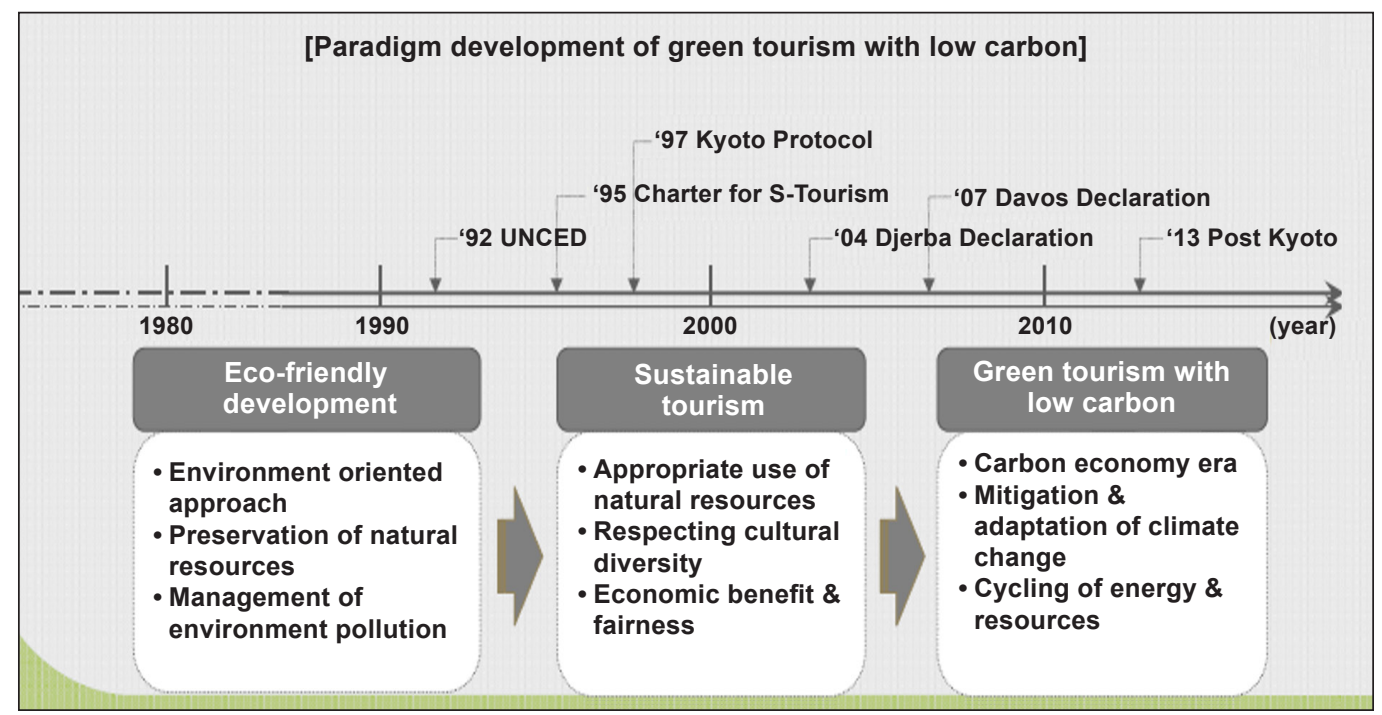

Figure 3. Paradigm development of green tourism with low carbon emissions Source: Lee (2011)

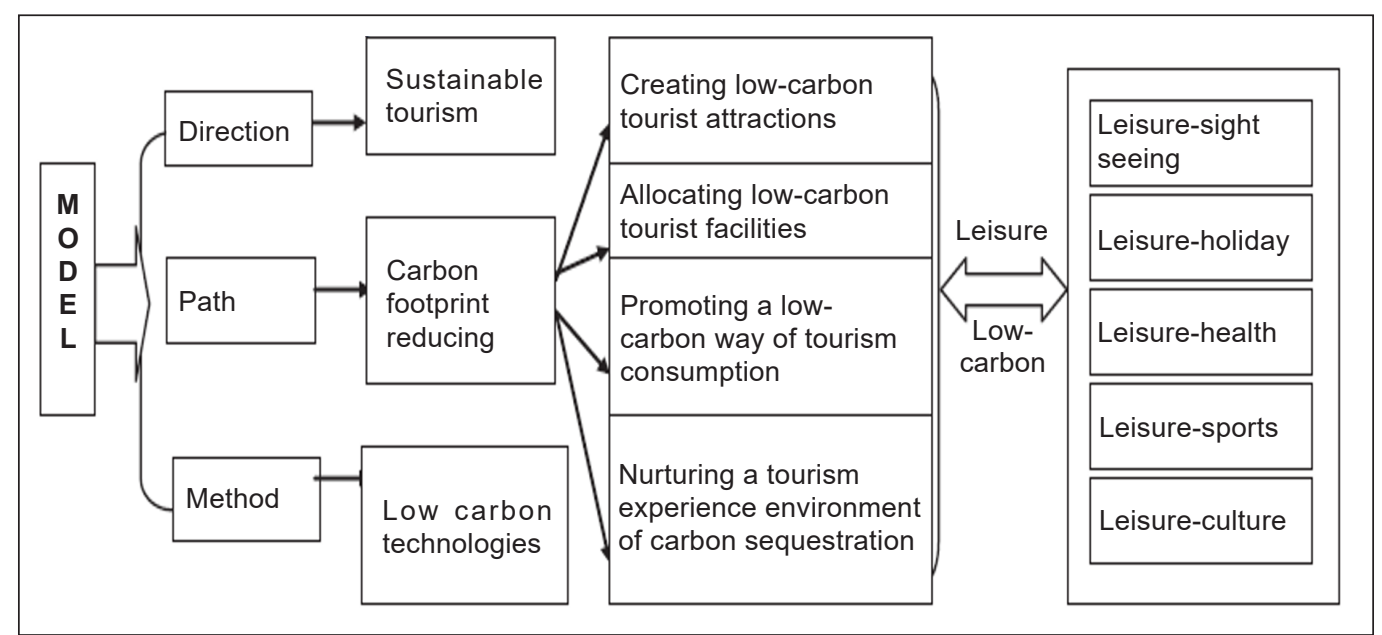

Figure 4. Low-carbon tourism development model in the leisure economy

Source: Huang \& Deng (2011)

As Figure 4 shows, LCT can be achieved by introducing low-carbon technologies to reduce the footprint of tourism activities. Thanks to these technologies, LCT can have a better, practical impact. For example, it can increase the choice of low-carbon infrastructures and facilities for transportation, housing, dining, and shopping. Also, the promotion of LCT must be enhanced to expose more visitors and locals to low-carbon projects, such as tree-planting initiatives. A collaboration between all parties, including agencies, communities, entrepreneurs, tourists, and 
governments, is necessary to foster lowcarbon practices and achieve LCT goals. The planning of strategic mechanisms by governments is also necessary for more effective implementation. One of the possible actions is to encourage or enforce low-carbon technology in every activity that uses energy in the tourism sector-for example, creating low-carbon buildings, transportation, equipment, and tourist attractions. Therefore, the LCT agenda needs to go beyond ecotourism; sociocultural factors need to be included to achieve the long-term goal of a low-carbon transition.

\section{Assessing the Effects of Implementing an LCT Programme}

Many studies have shown that tourism activities can improve the local economy, including in rural areas. Therefore, alternative tourism initiatives need to be introduced to provide win-win solutions that support local economies while upholding environmental conservation. Low-carbon programmes are initiatives to preserve the environment from pollution caused by tourism activities. Fang (2011) examined the efforts to make Pinglin a low-carbon rural tourism centre. Carbon vouchers are among the initiatives introduced there. These vouchers can be spent at "low-carbon stores," and $10 \%$ of each purchase will be a tree-planting fund to offset $\mathrm{CO}_{2}$ emissions. Furthermore, household waste will be stored and disposed of in people's homes to maintain cleanliness around the city. These activities require the support of all the parties involved to achieve the long-term goal of a low-carbon community. So, for an LCT project to succeed, it needs the support of the government and the locals.

\section{Covid-19 and LCT Development}

The Covid-19 pandemic has impacted both the international and local tourism sectors. The OECD (2020b) has shown that wellestablished tourist destinations worldwide are harmed the most by the pandemic. To curb the spread of the virus, governments have imposed various travel restrictions, including on tourism-based activities at the global and national levels. These restrictions included entry bans, testing, and quarantine measures; they are based on a set of risk-assessment criteria, such as the epidemiological situation in the countries of departure and arrival and the emergence of variants of the virus (European Observatory on Health Systems and Policies, 2021). The national response to the pandemic includes the closing of borders; travel restrictions; the closing of non-essential businesses, schools, and other public places; self-quarantine at home, mandatory quarantine in ad-hoc facilities or lockdowns; and the provision of economic stimuli (Fauziah, 2020).

The pandemic has had a severe impact on the tourism sector (Nagaj \& Žuromskaite, 2021). Although the Covid-19 pandemic hurts the health system and the world economy, the pandemics positively impact the environment. According to Nagaj and Zuromskaite (2021), the Covid-19 outbreak has decreased greenhouse gas emissions from tourism activities in all Central and 
Eastern European (CEE) countries. Due to restrictions on movement and travel, it covers domestic and international tourism that are enforced during the pandemic season to curb the spread of epidemics. Covid-19 prevents people from visiting tourist locations because a positive individual could potentially spread the virus. The pandemic has led to the closure of premises and tours, creating huge losses for operators and stakeholders. It has also reduced $\mathrm{CO}_{2}$ emissions resulting from transportation, accommodation, and activities that involve energy consumption in the tourism sector. However, this reduction will not affect global climate change if it remains temporary. As the OECD (2020a) has shown, there is no evidence that the Covid-19 pandemic will alter the course of climate change.

Many studies show that the impact of tourism on $\mathrm{CO}_{2}$ emissions is highly dependent on sustainable tourism policy and adaptation management (Paramati et al., 2017; Tian et al., 2021). According to Tian et al. (2021), the tourism sector can be an engine for reducing $\mathrm{CO}_{2}$ emissions, because in the long-term perspective, increasing tourism growth by $1 \%$ reduces pollutant emissions by $0.05 \%$. The study of Braga et al. (2020) showed the Covid-19 pandemic resulted in improved water quality in Venetian canals and lagoons through satellite imagery comparing it in 2019 and 2020. Although Covid-19 does not directly impact GHG emissions, it has nevertheless been proven to influence environmental health. Based on Environmental Impact Assessment (EIA; 2020) report, the Covid-19 crisis has reduced emissions with an estimated reduction of $8 \%$ of global $\mathrm{CO}_{2}$ emissions in 2020 compared to 2019 . However, it will not reduce the impact of climate change because it is temporary. Therefore, further action needs to be taken to curb climate change which has a worse impact. Thus, ensuring the regulatory impact on the tourism sector for beneficial changes in the environment can last longer. The concept of sustainable tourism, promoting the idea of slow tourism, and taking care of the natural environment must be implemented in future development strategies.

Indirectly, post-crisis recovery programs provide an opportunity to align public policy more closely with climate objectives and limit the risk of locking down carbonintensive infrastructure. Therefore, future stimulus packages need to be planned to encourage investment in sectors and technologies to accelerate the transition and increase resilience to future shocks due to climate change. In addition, governments need to ensure that emergency actions implemented to address the Covid-19 crisis do not frustrate efforts in addressing environmental challenges in tandem with efforts to improve environmental health and community resilience (OECD, 2020a). Studies from epidemiologists have found that exploiting the environment for development increases the risk of the emergence of various types of epidemics in the future (OECD, 2020a). IPCC (2019) predicts a worse situation impacted by climate change, such as the ice sheet's collapse in Antarctica. The melting of the Antarctic ice 
is now adding about 0.02 inches a year to global sea-level rise due to the effects of climate change (Stone, 2021). Accordingly, it is hoped that the Covid-19 pandemic could be a starting point to changes in attitudes and practices that reduce climate change mitigation. For example, reducing business travel by conducting online trading activities can reduce carbon emissions into the air. However, there are several effects of Covid-19 on the expansion of low-carbon ventures following the reduction in lowcarbon investment prospects. Efforts to empower low-carbon technologies, in the long run, require substantial investments in terms of innovation and dissemination (IPCC, 2019; OECD, 2010). Among the effects of Covid-19 on the reduction of low carbon investment are;

i. Uncertainty over the economic situation affected by the outbreak is much higher than the Global Financial Crisis, resulting in investors delaying investment activities and access to financing, including the energy industry and new technological innovations.

ii. The fall in oil prices of up to $60 \%$ recorded in February and March 2020 due to reduced demand provided weaker incentives for investment in low carbon technology and energy efficiency at all levels, from research and expansion to commercial deployment. According to the EIA (2021), United States crude oil production declined by $8 \%$ in 2020 due to a sharp reduction in petroleum demand in March 2020 as a result of the global response to Covid-19 causing crude oil operators to lower production.

iii. Most of the drivers of innovation and low-carbon technology consist of small companies that are more potentially affected by the Covid-19 crisis compared to larger or powerful firms because they have lower access to the capital needed to launch temporary shocks (Bell et al., 2020; OECD, 2020a).

These factors have led to global supply chain disruptions, including renewable energy projects, which slow or prevent the addition of renewable energy capacity in 2020 due to disruptions during outbreaks such as lockdown measures, physical distances and funding challenges in the coming years. The fossil fuel sector is important for energy security as a necessary resource for low-carbon transition, including supporting innovation in technologies that could transform the sector itself, such as the use and storage of carbon capture. The Covid-19 crisis may provide an opportunity to rethink the fossil fuel industry's role in this transition. Thus, pre-recovery support towards companies and industries is needed to help the low-carbon transition, such as avoiding lowering energy-efficient standards and climate policies and providing direct support to companies, which working on the environmental improvements. For example, they are providing green stimulus packages to support long-term recovery, such as encouraging investment 
in low carbon infrastructure (improving buildings, renewable energy infrastructure, communications networks, and public transport), increasing government efforts for innovation and new technology start-ups and setting federal carbon prices to maintain incentives while protecting vulnerable communities.

The Covid-19 crisis provides a lesson about society's vulnerability to global shocks that significantly impact human living norms; however, this crisis can also enhance the effectiveness of public policy by reducing GHG emissions, and increasing investment in new investments economic sectors in the long run. The pandemic has helped spread LCT strategies worldwide, especially through the imposition of limits on the use of carbon-intensive infrastructure (OECD, 2020a). Stakeholders should implement emergency measures to promote LCT development during the Covid-19 crisis
(OECD, 2020a). First, the management of the stock and composition of GHG emissions should occur not just in the short term. Second, as we know that the decline in emissions is temporary (based on past global crises, such as the 2008 financial crash), measures should be taken to make it even stronger in the following years. The OECD (2020a) proposes a blueprint for a low-carbon recovery, as shown in Table 2.

During the pandemic, border closures and travel bans became the worst obstacles in tourism development, adversely affecting the economy. As a result, tour operators lose their source of income resulting in losses. Accordingly, several new norms that must be adhered to as safety measures during the epidemiological season have been introduced in the tourism sector. Among the measures that need to be taken are disinfection of hotel rooms and other tourist facilities, mandatory disinfection,

Table 2

Blueprint for a low-carbon recovery

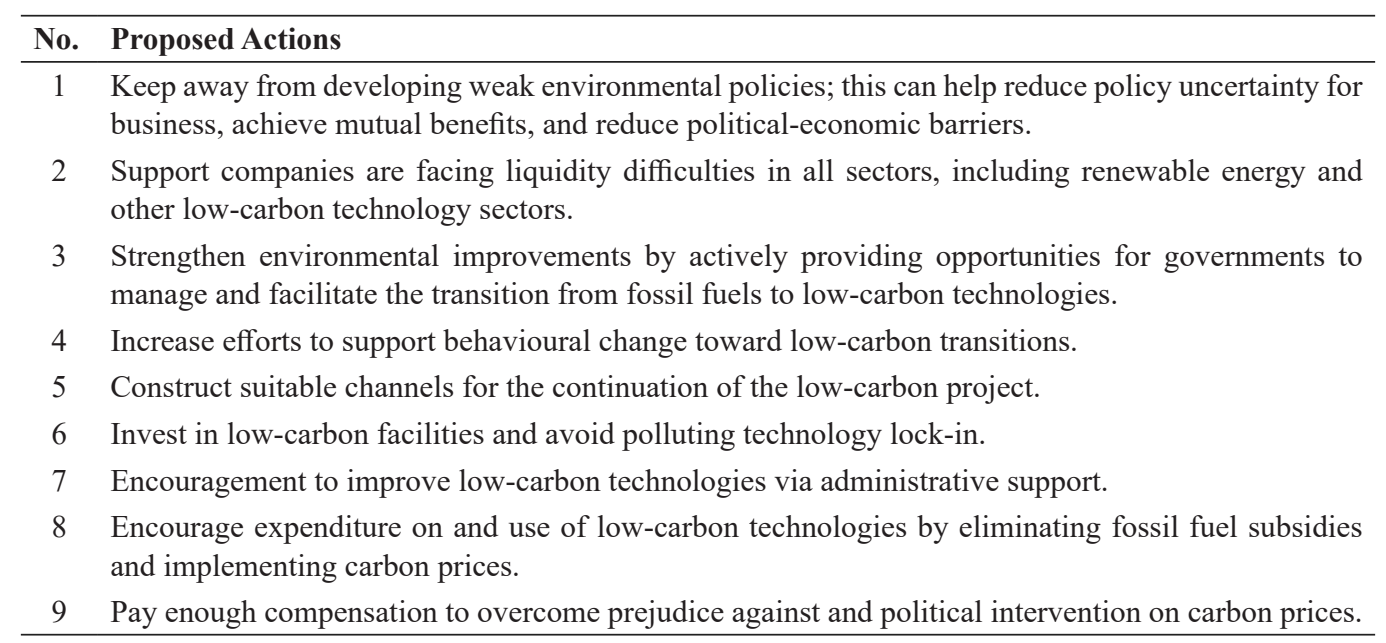

Source: OECD (2020a) 
temperature testing of users, limiting the number of people allowed to stay in one room. The impact of the tourism industry on the environment depends on the country and the nature of the local tourism industry. Thus, it raises the awareness that tourism development can be a machine to reduce energy consumption and $\mathrm{CO}_{2}$ emissions in the long run by adopting low-carbon tourism practices.

\section{DISCUSSION}

Traditional tourism practices can cause terrible resource waste. LCT can overcome this problem by introducing energy-saving practices that reduce pollution. Similarly, LCT can increase environmental protection awareness in food packaging, housing, and low-carbon transport. Thus, LCT can save natural resources from damage and exploitation. Moreover, low-carbon travel involves a relaxing mode of transport close to nature and can reduce the stress of modern life. Among the activities that can reduce stress are walking and cycling, which allow us to enjoy the scenery of nature - something that is impossible when using a motor vehicle. Air pollution, the energy crisis, and many other environmental problems cannot be solved only through technology and science but require the joint efforts of all parties. Therefore, developing a low-carbon lifestyle is the most effective way to solve the problems caused by rapid economic growth and the development of the tourism sector.

According to Sunlu (2003), tourism can help environmental conservation in four domains: financial contributions, better environmental management and planning, increased environmental awareness, and protection and maintenance. Through tourism activities, funds can be raised for the conservation of sensitive areas and habitats. For example, collecting money from entrance tickets or equipment rental can provide funds to manage natural resources and tourist attractions. This money can also be used for the salaries of rangers and maintenance workers. Careful management of tourism development and environmental planning is necessary to reduce the impact on nature. For example, green buildings are a way to reduce energy consumption and waste production. Increased environmental awareness is required to boost public appreciation of the environment. It will hopefully lead to better behaviour towards the environment and sustainable practices, thus ensuring the well-being of nature in the long run. Protection measures are essential for conserving biodiversity and guaranteeing the sustainable use of resources. Therefore, nature protection laws need to be enforced to safeguard valuable resources and assets. For example, certain islands in Malaysia rich in coral reef species (e.g., the marine parks of Tioman Island, Perhentian Islands, and Sabah) need proper controls so that natural resources are not threatened and can be enjoyed by future generations. The growth of coral reefs takes decades, but many are dying due to rising temperatures and seawater acidity (National Science Centre, 2020). Environmental policies such as programmes to protect coral reefs and 
wastewater recycling can help endangered species grow again.

Overall, the Covid-19 pandemic does not affect the development of LCT; instead, the pandemic can lead to a healthy environment by producing cleaner air for the population. All parties must ensure that their efforts to address pressing environmental challenges and improve society's resilience are followed up with strong climate policies (OECD, 2020b). Furthermore, governments can take an immediate step to ensure that the emergency actions implemented to combat Covid-19 do not thwart efforts to address environmental challenges and improve community resilience (OECD, 2020a).

\section{CONCLUSION}

Currently, unregulated economic growth is causing significant environmental damage. The rapidly growing tourism industry is no exception in this sense. Therefore, implementing a low-carbon approach can help protect increasingly endangered natural resources. There is a need for a stimulus package to boost LCT by encouraging investment in sectors and technologies that can speed up the green transition and increase societal resilience to future shocks caused by climate change. Further detailed research is needed to define LCT in terms of assessment systems, impacts, models, policies, regulations, incentives, and collective implementation measures. In Malaysia, non-renewable fuels-coal, crude oil, natural gas - are major energy sources in the tourism industry. It harms the environment through increased GHG emissions. However, LCT suggests that the use of renewable energy sources - biomass, wind, and solar - to develop resorts and other facilities can minimise emissions. Administrative departments, travel agencies, developers, traders, and entrepreneurs should support energy-saving initiatives in the tourism sector. We see low-carbon technological progress as very helpful in promoting the sustainable development of the tourism industry in Malaysia. Therefore, detailed research is required to produce a more efficient, economical, and comprehensive LCT model that can preserve natural resources, and ensure the well-being of future generations.

\section{ACKNOWLEDGEMENTS}

This article was funded through the Fundamental Research Grant Scheme (FRGS Code: 2020-0161-106-02). The authors would like to thank the Malaysia Ministry of Education for supporting this research.

\section{REFERENCES}

5 destinasi popular ini ditutup... puncanya kerana terlalu ramai pelancong! [These 5 popular destinations are closed ... because there are too many tourists!] (2019, September 29). MStar. https://www.mstar.com.my/travel/ destinasi/2019/09/29/destinasi-ditutup

Becken, S. (2009). The carbon footprint of domestic tourism. Technical report, The Hikurangi Foundation, Wellington. https://core.ac.uk/ download/pdf/35461014.pdf

Bell, B., Bloom, N., Blundell, J., \& Pistaferri, L. (2020, April 6). Prepare for large wage cuts if 
you are younger and work in a small firm. VOX CEPR Policy Portal. https://voxeu.org/article/ prepare-large-wage-cuts-if-you-are-youngerand-work-small-firm

Bhaktikul, K., Aroonsrimorakot, S., Laiphrakpam, M., \& Paisantanakij, W. (2020). Toward a low-carbon tourism for sustainable development: A study based on a royal project for highland community development in Chiang Rai, Thailand. Environment, Development and Sustainability, 23, 10743-10762. https://doi. org/10.1007/s10668-020-01083-4

Bohdanowicz, P., Churie-Kallhauge, A., \& Martinac, I. (2001, April 5-7). Energy-efficiency and conservation in hotels-Towards sustainable tourism [Paper presentation]. $4^{\text {th }}$ International Symposium on Asia Pacific Architecture, Honolulu Hawaii, United States.

Braga, F., Scarpa, G.M., Brando, V.E., Manfè, G., \& Zaggia, L. (2020). COVID-19 lockdown measures reveal human impact on water transparency in the Venice Lagoon. Science of the Total Environment, 736(2020), Article 139612. https://doi.org/10.1016/j.scitotenv.2020.139612

Chiesa, T., \& Gautam, A. (2009). Towards a low carbon travel \& tourism sector. World Economic Forum (Aviation, Travel \& Tourism Partnership Programme). https://sustain.pata.org/wp-content/ uploads/2015/02/STO-LOW-CARBONTRAVEL-TOURISM-SECTOR.pdf

Durojaye, O., Laseinde, T., \& Oluwafemi, I. A. (2020). A descriptive review of carbon footprint. In $\mathrm{T}$. Ahram, W. Karwowski, S. Pickl, \& R. Taiar (Eds.), Human systems engineering and design II. IHSED 2019. Advances in Intelligent Systems and Computing, Vol. 1026 (pp. 960-968). Springer, Cham. https://doi.org/10.1007/978-3030-27928-8_144

Environmental Impact Assessment. (2020, January 14). New electric generating capacity in 2020 will come primarily from wind and solar, United
State Energy Information Administration. https://www.eia.gov/todayinenergy/detail. php?id=42495

Environmental Impact Assessment. (2021, May 6). Energy production in the United States fell by more than 5\% in 2020. United State Energy Information Administration. https://www.eia. gov/todayinenergy/detail.php?id=47856

European Observatory on Health Systems and Policies. (2021). COVID-19 response: How have international travel restrictions affected freedom of movement during the pandemic? https:// eurohealthobservatory.who.int/news-room/ events/item/2021/06/29/default-calendar/covid19-response-how-have-international-travelrestrictions-affected-freedom-of-movementduring-the-pandemic

Fang, Y. I. (2011). Is low carbon tourism a good incentive for the development of a low carbon community? A case study of the Pinglin District [Master's thesis, Lund University]. International Master's Programme in Environmental Studies and Sustainability Science (LUMES). http:// www.lumes.lu.se/sites/lumes.lu.se/files/fang_ ying_chen_thesis_2011.pdf

Fauziah, C. L. (2020). The geography of accessibility: Assessing the Malaysian approach to Covid-19 pandemic management. Geografi, 8(2), 66-91. https://doi.org/10.37134/geografi.vol8.2.4.2020

Huang, C., \& Deng, H. (2011). The model of developing low-carbon tourism in the context of leisure economy. Energy Procedia, 5(2011), 1974-1978. https://doi.org/10.1016/j. egypro.2011.03.339

Intergovernmental Panel on Climate Change. (2019). Global warming of $1.5^{\circ} \mathrm{C}$. Special Report. https:// www.ipcc.ch/sr15/

Lee, W. H. (2011). Climate change and tourism policy for low-carbon green tourism. Korea Culture \& Tourism Institute. 
Ministry of Land, Infrastructure, Transport and Tourism Japan. (2011). Low carbon city development guidance [outline]. https://www. mlit.go.jp/en/toshi/city_plan/toshi_city_plan_ fr_000000.html

Mohamad, S. H., \& Jaafar, H. I. (2012, May 19). Development of renewable energy sources according to Islamic perspective [Paper presentation]. Third National Conference Fiqh Science and Technology. https://www. researchgate.net/publication/244995379_ Pembangunan_Sumber_Tenaga_Yang_Boleh_ Diperbaharui_Mengikut_Perspektif_Islam

Nagaj, R., \& Žuromskaite, B. (2021). Tourism in the era of Covid-19 and its impact on the environment. Energies, 14, 2000, 1-18. https:// doi.org/10.3390/en14072000

National Science Centre. (2020). Is the fading of coral reefs getting more serious? Malaysia Ministry of Science, Technology, and Innovation. http:// www.psn.gov.my/

Organisation for Economic Co-operation and Development. (2010). Tourism 2020: Policies to promote competitive and sustainable tourism. In OECD Tourism trends and policies 2010. OECD Publishing. https://doi.org/10.1787/ tour-2010-4-en

Organisation for Economic Co-operation and Development. (2020a). COVID-19 and the low-carbon transition: Impacts and possible policy responses. OECD Publishing. https://doi. org/10.1787/749738fc-en

Organisation for Economic Co-operation and Development. (2020b). Tourism policy responses to the coronavirus (COVID-19). https://read. oecd-ilibrary.org/view/?ref=124_1249847 uf8nm95se \&title $=$ Covid

Pandey, D., Agrawal, M., \& Pandey, J. S. (2010). Carbon footprint: Current methods of estimation. Environmental Monitoring and Assessment,
178(2011), 135-160. https://doi.org/10.1007/ s10661-010-1678-y

Paramati, S.R., Shahbaz, M., \& Alam, M.S. (2017). Does tourism degrade environmental quality? A comparative study of Eastern and Western European Union. Transportation Research Part D (2017), 50, 1-13. https://doi.org/10.1016/j. $\operatorname{trd} .2016 .10 .034$

Salehudin, M. S., Prasad, D. K., \& Osmond, P. (2015, November 30-December 2). Renewable energy potential for energy-efficient resort development in Malaysia [Paper presentation]. Solar 2011, the $49^{\text {th }}$ AuSES Annual Conference, Sydney Australia.

Shi, C. B., \& Peng, J. J. (2011). Construction of lowcarbon tourist attractions based on low-carbon economy. Energy Procedia, 5(2011), 759-762. https://doi.org/10.1016/j.egypro.2011.03.133

Stone, M. (2021, May 5). Antarctica's ice could cross this scary threshold within 40 years. National Geographic. https://www.nationalgeographic. com/environment/article/antarcticas-ice-couldcross-this-scary-threshold-within-40-years

Sunlu, U. (2003). Environmental impacts of tourism. In D. Camarda \& L. Grassini (Eds.), Local resources and global trades: Environments and agriculture in the Mediterranean region ( $\mathrm{pp}$. 263-270). Options Méditerranéennes: Série A. Séminaires Méditerranéens; n. 57. CIHEAM. https://om.ciheam.org/om/pdf/a57/04001977.pdf

Tang, Z., Bai, S., Shi, C., Liu, L., \& Li, X. (2018). Tourism-related $\mathrm{CO}_{2}$ emission and its decoupling effects in China: A spatiotemporal perspective. Advances in Meteorology, 2018, 1-10. https:// doi.org/10.1155/2018/1473184

Thongdejsri, M., Nitisoravut, R., Sangsnit, N., Kunkuamdee, P., Muongpruan, C., \& Nitivattanon, V. (2016). A pilot project for promoting low carbon tourism in designated areas of Thailand. Proceedings of the International 
Academic Research Conference on Marketing \& Tourism (MTC16 Swiss Conference) http:// globalbizresearch.org/Swiss_Conference_2016_ July/docs/doc/3.\%20Management $\% 20 \& \% 20$ Marketing/ZM609.pdf

Tian, X.L., Bélaïd, F., \& Ahmad, N. (2021). Exploring the nexus between tourism development and environmental quality: Role of Renewable energy consumption and Income. Structural Change and Economic Dynamic, 56, 53-63. https://doi.org/10.1016/j.strueco.2020.10.003

Wang, Q., Mao, Z., Xian, L., \& Liang, Z. (2019). A study on the coupling coordination between tourism and the low-carbon city. Asia Pacific Journal of Tourism Research, 24(6), 550-562. https://doi.org/10.1080/10941665.2019.1610002

Xiong, W. P. (2017). A study on rural lowcarbon tourism development in Jiangxi. IOP
Conference Series: Earth and Environmental Science, 61(2017) 012059, 1-5. https://doi. org/10.1088/1755-1315/61/1/012059

Yang, Y. F. (2015). Implementation strategies of low-carbon tourism. The Open Cybernetics \& Systemic Journal, 9, 20032007. https://pdfs.semanticscholar.org/c3ae/ cc8c18d209c9dc2cb026d4ed0f6fce2a36cd. pdf?_ga=2.94651548.1244809929.1610867639180003756.1610867639

Zakaria, J., \& Hasbullah, N. A. (2009, January 3031). Challenge-based recreational tourism and biodiversity: Issues and conflicts [Paper presentation]. UKM National Conference on Environmental Studies, Bangi Selangor, Malaysia. 
